\title{
Hot pyroclastic deposit as lahar resistor: a case study of Gendol River after the Mt. Merapi 2010 eruption
}

\author{
S. Sandy Putra, C. Hassan \& S. Hariyadi \\ Research Centre for Water Resources, Indonesia
}

\begin{abstract}
The year 2010 left unforgettable memories for Indonesian people because of the Mega Eruption of Mt. Merapi, which was predicted as the biggest eruption since 1870. Lahar became a dangerous secondary hazard around the Mt. Merapi watershed. The lahar event record until February 2011 in Gendol Watershed showed less instances of lahar occurrence compared with other areas, such as River Putih WS ( $>10$ events), River Apu WS ( $>5$ events), etc. This paper provides literature analysis, stratigraphy study analysis, and also temperature measurement reports, in association with lahar triggered factors in the Gendol Watershed. Previous stratigraphy survey data on Gendol River (Newhall et al., Journal of Volcanology and Geothermal Research, 2000) shows that the pyroclastic deposit material allows water infiltration because of its porosity. The conditions of a deep clay (impermeable) layer and no water table found up to $\pm 11 \mathrm{~m}$ depth support rain water infiltration. The post eruption pyroclastic deposit is still at a high temperature $\left( \pm 105^{\circ} \mathrm{C}\right)$, which causes some infiltrated water to be evaporated. Less runoff will promote a smaller amount of sediment transport and less risk and lower destructive force of a lahar event. Over a sufficient period, the pyroclastic deposit will be consolidated and compacted as a result of the cementation process of active pyroclastic elements (solidified by chemical bonding). Hot pyroclastic material in the Gendol River after the Mount Merapi Eruption 2010 could have acted as a resistor for lahar. The resist period was \pm 145 days, from the first eruption until the significant lahar event. The influential resistance factors are thickness, density, porosity, riverbed gradient, rain intensity, and temperature of the pyroclastic deposit. It gives enough time for urgent action (human relocation), environment mitigation, reconstruction, and remediation in the watershed. This fact was the empirical basis for the
\end{abstract}


emergency countermeasure priority rating of several lahar rivers, in a volcanic eruption event.

Keywords: Merapi, eruption 2010, pyroclastic, temperature, lahar resistor.

\section{Introduction}

The year 2010 left unforgettable memories for Indonesian people because of the Mega Eruption of Mt. Merapi. Preceded by an increase in seismic activity in mid-September, Mount Merapi then exploded giving out very large amounts of volcanic material $\left( \pm 150\right.$ million $\left.\mathrm{m}^{3}\right)$, forming a high ridge of volcanic smoke $(\geq 3 \mathrm{~km})$, and spewing out pyroclastic clouds that glided with a range of about $17 \mathrm{~km}$ from the mountain top (maximum range that reached Argomulyo Village, River Gendol Watershed), burning several villages on the slopes of Merapi. Based on data from the Geological Agency, Ministry of Energy and Mineral Resources, the eruption of Mt. Merapi in 2010 is recorded as the largest Merapi eruption since 1870 .

By the announcement of Mount Merapi status becoming "Waspada" (advisory level of Volcano Alert Levels used by USGS Volcano Observatories) on December 30, 2010, the primary hazard impact period of the Mount Merapi eruption had been over. Lahar flow then became the secondary hazard that needed to be anticipated. Furthermore, in January to March, the Indonesian Archipelago entered the wet season, characterized by high intensity and frequency of rain.

Lahar floods continue to threaten people who live along the rivers upstream from the slopes of Mount Merapi. The eruption material of Mount Merapi was predicted to attain 130 cubic meters and is concentrated in eight of the rivers upstream as shown in table 1.

Table 1: The eruption material of Mount Merapi which was concentrated in 8 surrounding Lahar Rivers (Mujiharjo et al. [1]).

\begin{tabular}{|c|c|c|}
\hline No. & Lahar River & Pyroclastic deposit amount $\left(\mathrm{m}^{3}\right)$ \\
\hline 1 & Boyong & 8 million \\
\hline 2 & Bebeng & 10 million \\
\hline 3 & Blongkeng & 10 million \\
\hline 4 & Woro & 12 million \\
\hline 5 & Kuning & 14 million \\
\hline 6 & Putih & 18 million \\
\hline 7 & Pabelan & 24 million \\
\hline 8 & Gendol & 28 million \\
\hline \multicolumn{3}{|c|}{} \\
\hline
\end{tabular}

Kali Gendol (Indonesian people call a "river" by the term "kali") is one of the rivers which disgorge from the Merapi crater area. Kali Gendol has high possibilities of receiving pyroclastic material from the lava dome. Kali Gendol has $\mathrm{a} \pm 16.50 \mathrm{~km}$ by $\pm 7.73 \mathrm{~km}^{2}$ watershed area, flowing downstream into Kali 
Opak. Some of the vital infrastructures in the Gendol Watershed that must be protected are Yogyakarta-Surakarta and Surakarta-Wonosari highway bridges, Prambanan Traditional Market, Cangkringan District headquarters, etc. The monumental heritage area which should be secured is the historic site of Prambanan Temple and Sewu Temple, temples with past history records of Hindu.

Meanwhile, in spite of all the Gendol Watershed susceptibility to lahar flow, lahar recorded events in the Gendol Watershed until February 2011 were fewer in number compared with other watersheds on the Merapi slope, such as the Kali Putih Watershed ( $>10$ events), Kali Apu Watershed ( $>5$ events), and so forth.

Starting from this background, this research sought a review of the pyroclastic deposit characteristics in Kali Gendol related to the factors that triggered the occurrence of lava flows. Analytical studies have been conducted to determine actions that need extraordinary consideration as Lahar disaster mitigation efforts. The result of this study could hopefully be the experimental concern for an emergency countermeasure priority rating of several lahar rivers, in the event of volcanic eruption.

\section{The conditions of pyroclastic deposits}

Pyroclastic deposits are formed by the material that accumulates from volcanic eruption activity that is released into the air during an explosion and falls back to the ground by the force of gravity (Houghton et al. [2]). Pyroclastic material, which is generally in the form of fine materials such as fine grain pumice stone (fine-grained pumice), lapilli (2-64 $\mathrm{mm}$ grain size) and volcanic ash (particle diameter $<2 \mathrm{~mm}$ ), falls down from the crater, and then follows the natural conditions such as wind speed and wind direction, where the distance that can be reached depends on the scale of the eruption (Kusumosubroto [3]).

The deposition of volcanic ash covering the pyroclastic deposits can reduce the soil surface capacity in absorbing rain water thus increasing run-off in a certain period of time, until the content of the volcanic ash upon the pyroclastic deposits have been reduced. Rain precipitation will draw the volcanic ash, which has a small mass, to be transported through surface runoff. The accumulation of that certain characteristic of flow can then form a mud flow.

\subsection{Stratigraphical data}

A stratigraphic survey conducted specifically at the location of Kali Gendol by Newhall et al. [4], to a depth of $\pm 11 \mathrm{~m}$ from ground level, shows that there is accumulation of pyroclastic material caused by several events of the Mount Merapi eruption. The boring test was conducted in Kali Gendol, Klangon, above Sragen (Merapi Golf Course), fig. 2.

The boring result, fig. 1, shows that the clay layer began to appear at a depth of $\pm 8 \mathrm{~m}$ (layer 18). A layer of pyroclastic deposits from several Merapi eruption events is visible up to a depth of $\pm 5 \mathrm{~m}$ (layer 10). Up to $\pm 11 \mathrm{~m}$ of boring, the 
ground water table was not found. This fact shows that the layers of pyroclastic deposits have a high porosity.

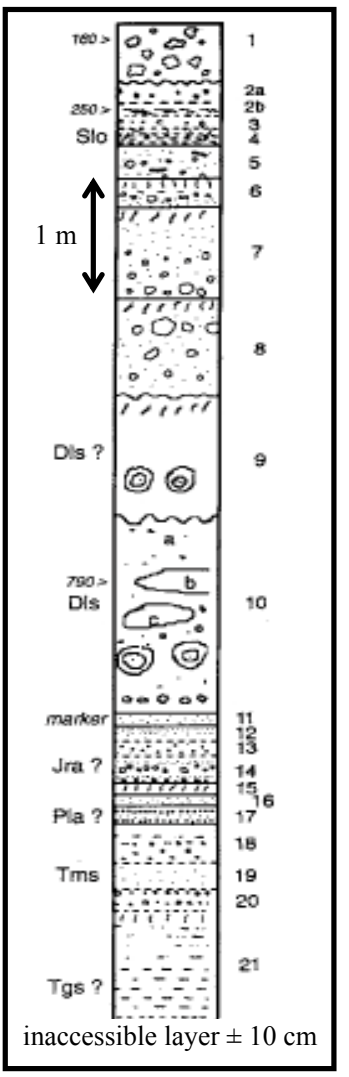

Explanations:

1. Pyroclastic-flow deposit; bomb-rich, age $=160 \pm 30$ y. Possibly associated with previous pyroclastic flows before boring (\#6, Bronto and Sayudi [5]) at a golf course, from the 1822 or 1872 eruption.

2. (a) Pyroclastic-flow deposit (= Pyro. flow 5 of Bronto and Sayudi [5]), (b) Pyroclastic-surge deposit, fines-poor, charred bamboo; $250 \pm 60 \mathrm{y}$.

3. Yellow-tan pumiceous airfall lapilli, with dense gray lithics of about $4 \mathrm{~cm}$ in diameter.

4. (a) Light grey, fine, clayey ash, (b) Tephra fall; granules and small lapilli, (c) Light-grey fine, clayey ash $(4 \mathrm{a}-\mathrm{c}=\mathrm{Slo})$.

5. Dark brown, massive pyroclastic-flow deposit, sand and lapilli, charcoal (= Pyro. flow 4 of Bronto and Sayudi [5])

6. Pyroclastic-flow deposit (\#3 of Bronto and Sayudi [5]), reverse graded, with charcoal, weathered top.

7. Pyroclastic-flow deposit ( $\# 2$ of Bronto and Sayudi [5]), normally graded, blocky hb andesite lithics in base; pumiceous lapilli in center grading up to dk brown siltysandy ash, w/ charcoal.

8. Pyroclastic-flow deposit (\#1 of Bronto and Sayudi [5]), approaching layer 7.

9. Tan, stratified ash with giant ant-cemented concretions ("ant balls," $6 \mathrm{~cm} \mathrm{dia.)} \mathrm{Probable} \mathrm{surge} \mathrm{deposit.} \mathrm{Soil} \mathrm{on} \mathrm{top.}$ (=Dls? (as identified by Andreastuti et al. [6])).

10.(a) Thick, crudely stratified ash with discontinuous layers of lithic and pumiceous lapilli; also with giant ant balls and at least one rip-up clast (c) A lens or second rip-up clast (b) grey, fines-depleted overbank pyroclastic flow deposit. Age $=790 \pm 50$ y. (= Dls (as identified by Andreastuti et al. $[6]))$.

Figure 1: Composite stratigraphy of Merapi Pyroclastik deposit in a specific site around Kali Gendol (Newhall et al. [4]).

\subsection{Temperature test}

In order to enhance the characteristic recognition of 2010 post eruption pyroclastic deposits at Kali Gendol, a series of temperature tests were carried out in different locations and at different times. The temperature test equipment consisted of a thermometer, stopwatch, scaling pole, hand bore utilities, crowbar, spade, hammer, stake pole, etc. The testing materials were pyroclastic deposits and chicken eggs.

The testing procedure consists of several steps, fig. 3. Firstly, the testing location is cleaned and cleared. The temperature of pyroclastic deposit material on the upper surface is measured ( $\pm 5 \mathrm{~cm}$ from the surface). The next step is boring (making holes) as deep as hand boring utilities could reach, considering the existence of stone and cobbles. The specimen, in the form of a chicken egg, 
is buried with the material from the bottom of about $\pm 5 \mathrm{~cm}$ of thickness, the thermometer was installed, and the time began to be recorded. After a certain duration, the temperature indicated on the thermometer was recorded, and then the egg was taken out. The boiled chicken egg was then split in a half and its transformation due to the pyroclastic material temperature was checked. The temperature test result is shown in table 2 and the cross sectional scheme of testing points is shown in fig. 4 .

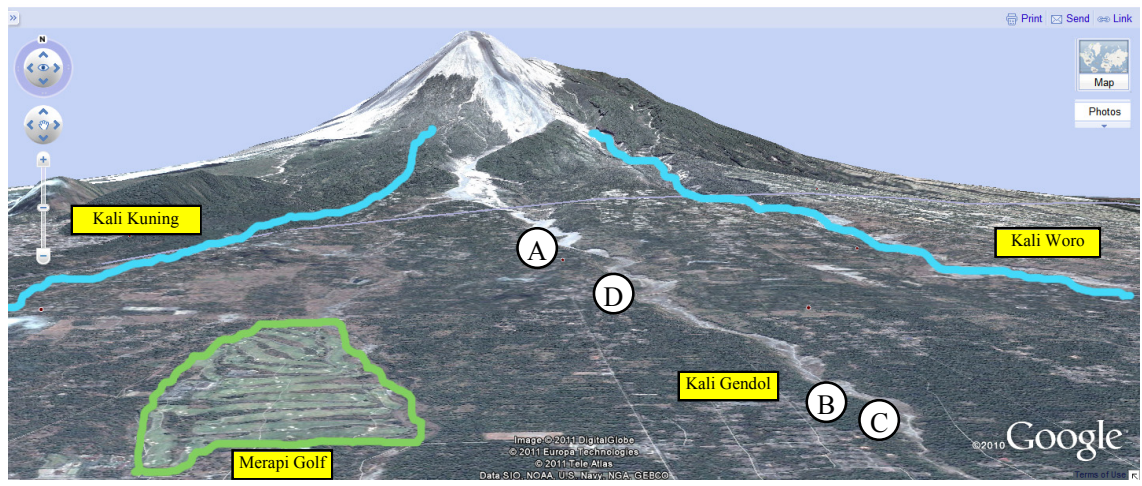

Figure 2: Three-dimensional view of the Kali Gendol Watershed. (A), (B), and $(\mathrm{C})$ are temperature test locations of pyroclastic deposits around Kali Gendol, whereas (D) is a stratigraphic boring location by Newhall et al. [4] (source: maps.google.com).

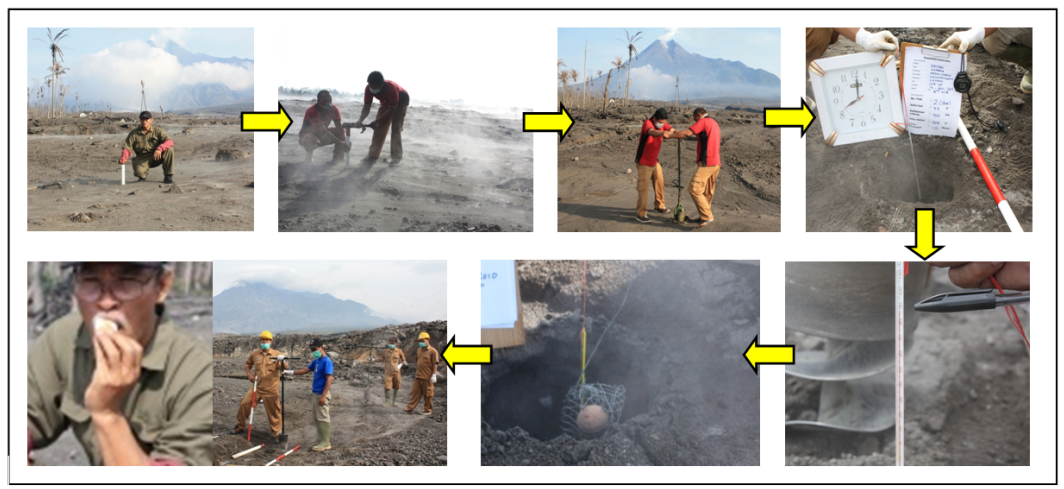

Figure 3: The sequence of pyroclastic deposit temperature measurements conducted by the Balai Sabo Team, Indonesia.

The thermal conductivity and the specific heat capacity of the pyroclastic deposits correspond to its heat conduction and the typical solid-fluid heat transfer. The hydraulic conductivity and effective porosity are important 


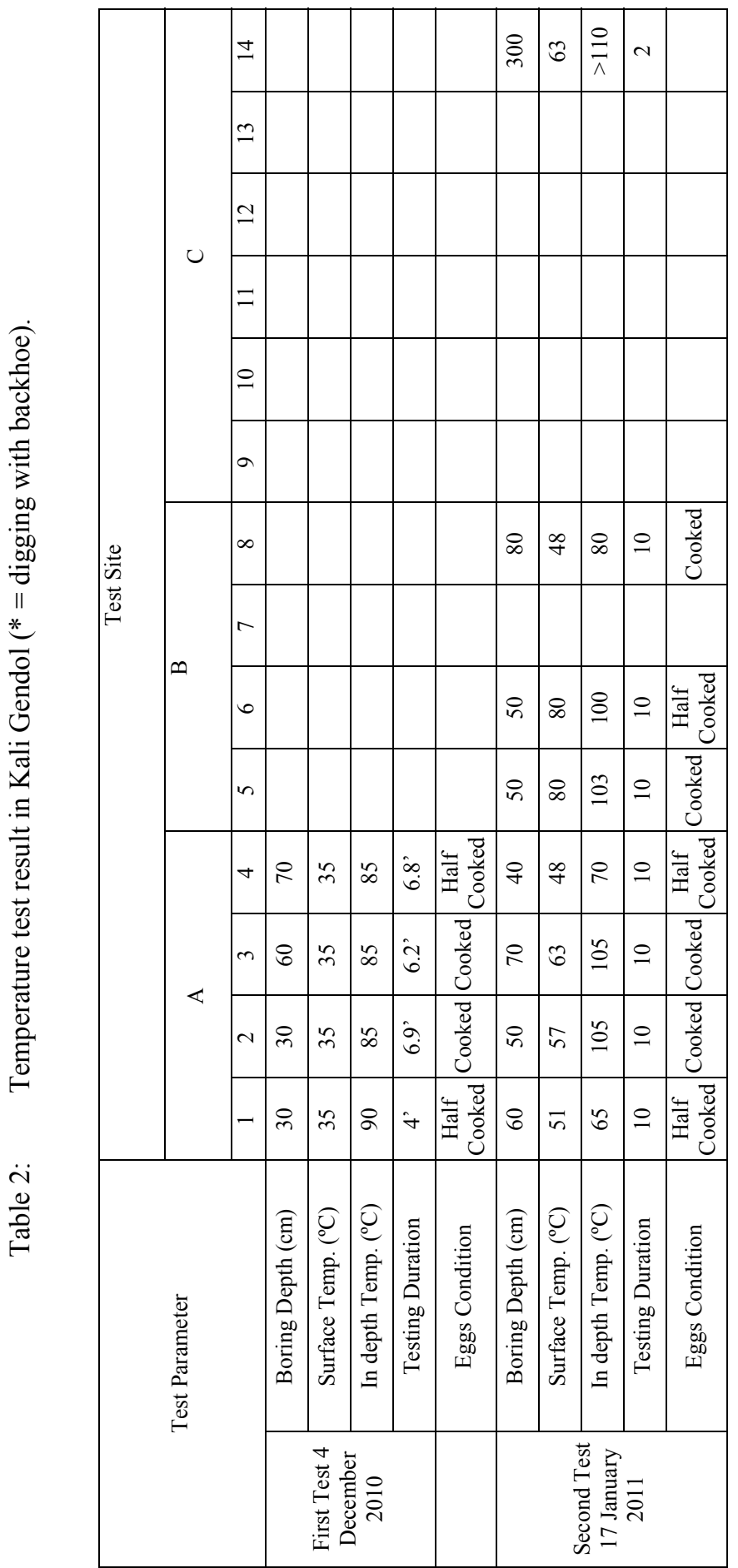




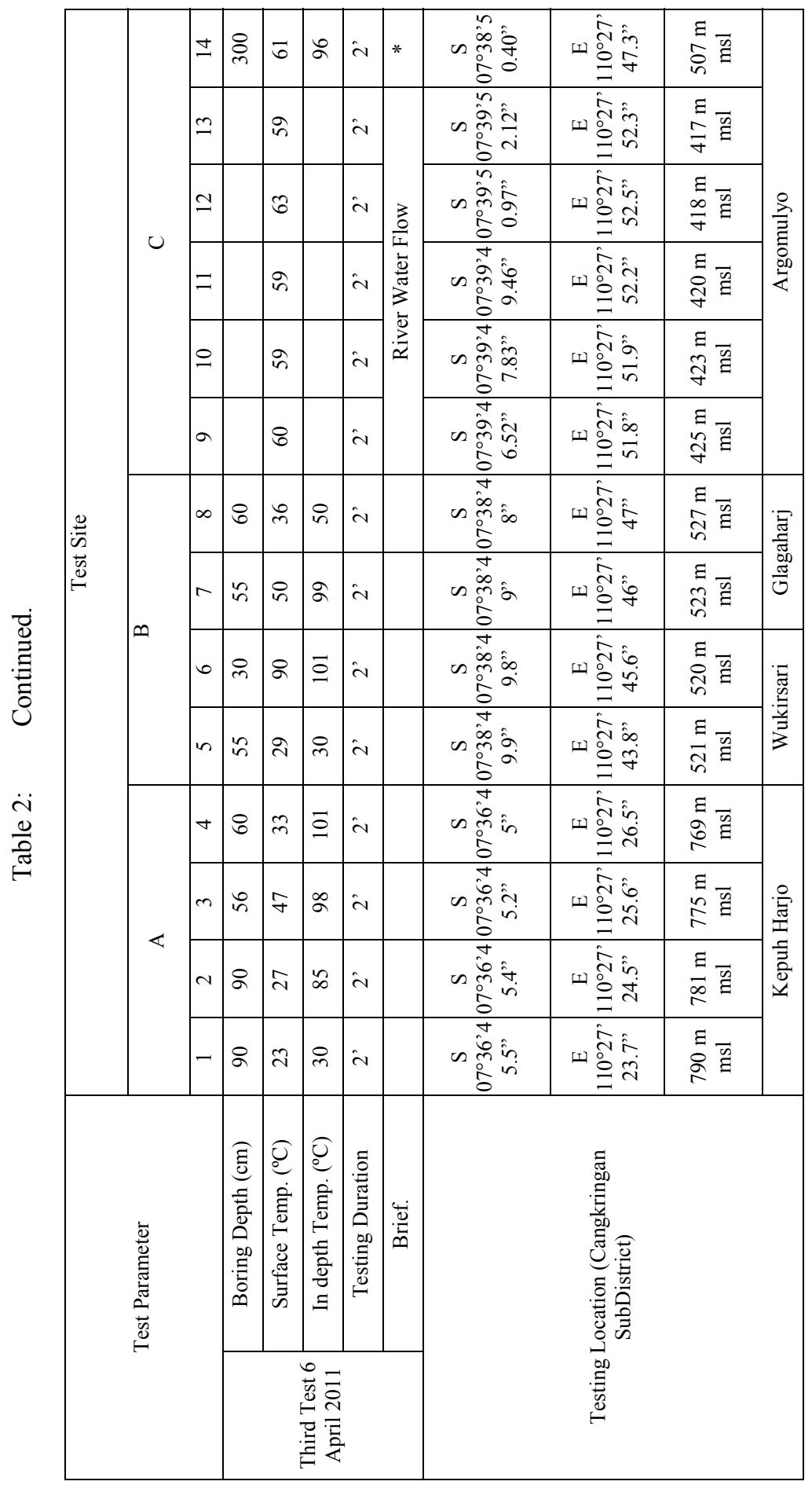


parameters that affect the pyroclastic deposit convection characteristic. The methods of heat transfer in the aquifer are the total effective thermo-mechanical dispersion and thermal diffusion (Fossoul et al. [7]). A porous medium with a larger porosity can provide more heat dissipation than a smaller mean porosity medium (Fu et al. [8]).

All these results can be summarized in the fact that pyroclastic deposits can store heat for a certain period of time only. In applications where very slow heat transfer rates are required, where as much heat as possible must be stored, the pyroclastic deposit should pass the consolidation and cementation processes.
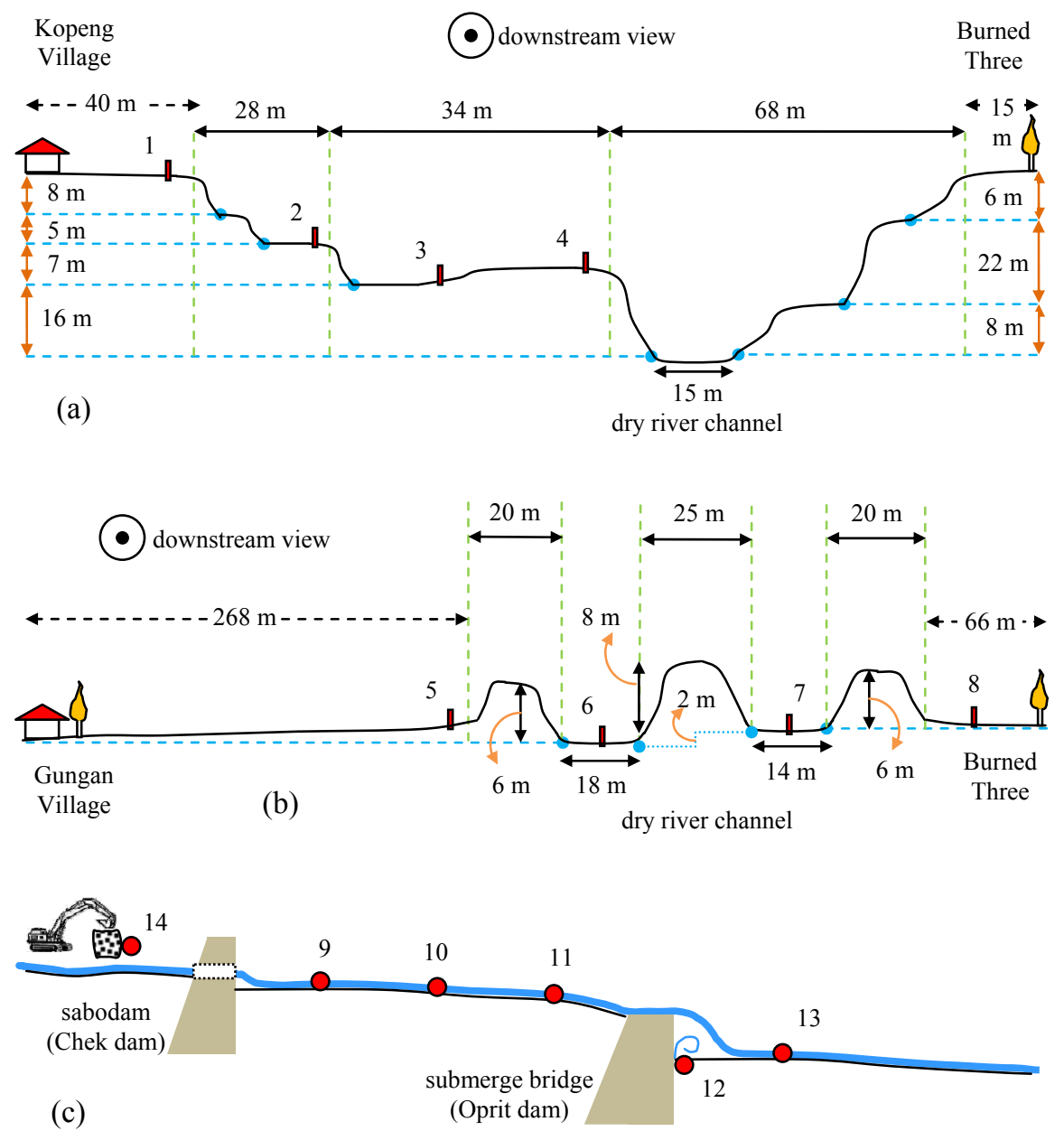

Figure 4: Cross section of Gendol River with temperature test points (a) first location (a), (b) second location (b), and (c) long section of third location (c). 


\section{Lahar resistor}

Lahar flow is the mixture of water and erupted volcanic material that slides down through the river valleys or grooves (Houghton et al. [2]). Hazards caused by lahar flows have been generated by rain, after or during eruption, and or a dam break. Lahar flow solid material is usually derived from a weather-beaten layer of volcanic ash and other materials carried by the flow around the river. The flow in a certain condition could then being accumulated as a high concentration flow, and than become debris flow. Sometimes the flow is still at a high temperature, which depends on the heat and thickness of the pyroclastic deposits' source. Hot lahar flow could be seen by the immediate withering of the leaves of nearby plants.

\subsection{Lahar flow characteristics}

Because of its enormous inertia, lahar flow does not turn easily and tends to take the shortest path. Therefore, the morphology of a river passing by lahar could change into a flat river plain, in only a short time (several hours). Lahar flow occurrence is difficult to predict, becoming a silent threat for people that live or have an activity around the river. In fact, as seen from several lahar events in the Mount Merapi area, these incidents can be very harmful to settlements and the objects in the vicinity of the rivers. Based on empirical study in the Merapi area, lahar flow occurred at an intensity of rainfall of $70 \mathrm{~mm}$, with a duration of 35 minutes, at an elevation of over than $1200 \mathrm{~m}$ (Legowo [9]). During the recent 2010 Mount Merapi post eruption period, lahar events were typically triggered by heavy rains on the slopes of the mountain, almost on every side of the mountain, but especially in locations with large pyroclastic deposits, which burned and buried the covering vegetation and forest area (Lavigne et al. [10]).

The impact of water triggered lava can not be underestimated. It is widely understood that rainfall is a significant control on the occurrence of lava, and this factor should have a greater weight in a case study of Merapi (Cully [11]). Rainfall intensity and duration of rain is very important, especially in an area with high rainfall and strong seasonal climate pattern, as in Indonesia. Watershed morphology is also a main factor in lahar analysis, but probably more subordinate than rainfall, because in this case water is a critical component for the formation of lahar. Landslides could also trigger the formation of lahar. Landslide triggered lahars, in many cases, could be larger and more dangerous than rain triggered lahars, but it seems to be a much rarer occurrence. Riverbank landslides will form a natural dam that dam up the stream. When the natural dam stability cannot cover the hydrostatic force caused by water that accumulates in the hillside, the natural dam will fail and a certain horrible disaster, which resembles a dam break tragedy, could occur.

\subsection{Lahar resistance factor}

Based on the test results, Kali Gendol pyroclastic deposits still have a high temperature $\left( \pm 100^{\circ} \mathrm{C}\right)$. That condition causes some infiltrated rain water to 
evaporate. The stratigraphic condition from drilling results indicates that water can still infiltrate to a depth of $\pm 5 \mathrm{~m}$, because the major component of pyroclastic deposits is porous material. The deeply positioned clay layer and the nonexistence of the ground water table up to a depth of $\pm 11 \mathrm{~m}$ are conditions that strongly support the rain water absorption. The greater porosity and higher temperature of the pyroclastic deposit will cause more rainwater to be evaporated by the heat of the pyroclastic deposits. By this condition, the run-off water would be reduced so that the destructive risk of lahar flow would be reduced.

The high temperature of the pyroclastic material can last up to a number of months or even years, depending on the deposit thickness and rain characteristic. Meanwhile, the lava dome formed by the 2010 Merapi eruption which tends to lead into the Kali Gendol can be further investigated using the methods developed by BPPTK (Nandaka and Asman [12]) has caused a huge amount of pyroclastic material to be deposited in that river. All these conditions provide sufficient time for pyroclastic deposits to be consolidated and more compacted due to the cementation process (hardening due to chemical bonding) among active pyroclastic elements. By these processes, it will prove to be more difficult to wash the pyroclastic material away by water flow. The resist period was \pm 145 days, from the first eruption until the significant lahar event (founded on the Gendol River observation, Mt. Merapi 2010 Eruption).

The internal influential resistance factors of lahar flow are thickness, density, porosity, and all other governing parameters in temperature equilibrium of pyroclastic deposits. For a further detailed measurement of thermal equilibrium (heat transfer $\left({ }^{\circ} \mathrm{C} /\right.$ time $\left.)\right)$ in a saturated porous medium in transient conditions, the Pantakar equation can be used (Pantakar [13]). The external resistance factors are riverbed hydraulic gradient, riverbank stabilization, rain intensity, sand mining and other human activities.

\section{Morphological adaptation of Gendol watershed}

\subsection{Volcanic eruption impact}

Volcanic processes, during and after the eruption, may impact in various ways on the surrounding fluvial system, fig. 5. The effects include the extraordinary volcanic clastic sediment supply, drainage system disturbance, the changes of river geometry and flow pattern, and, moreover, the formation and failure of natural dams. Depending on the range and frequency of events that disrupt the fluvial systems, fluvial systems could be "recovered" within a certain period of years or may change to another type of morphology. The conservation capacity and potency evaluation studies, which are based on the analogy of fluvialvolcanic systems that existed in the past, should be learnt in order to deal with the problems in Kali Gendol (Shea et al. [14]).

Material deposits of the 2010 Merapi volcanic eruption cover an approximate area of $286 \mathrm{~km}^{2}$, with a global average thickness of about $0.5-2 \mathrm{~m}$. Extreme conditions occurred in Kali Gendol, with an embankment material thickness of up to $25 \mathrm{~m}$ being common. The width of the buried valley of Kali Gendol has reached the range of $200 \mathrm{~m}$. The immediate actions that need to be carried out 
after the disaster are land use management, making an initial waterway and normalization of a river channel, the construction of temporary river control structures, and determining the sand mining location. The main purpose is how to maintain the stream path against fluctuation, so that lahar flows will not attack the settlement. Land remediation is necessary to recover the ecohydraulic characteristics of Kali Gendol.

The Mt. Merapi 2010 eruption has changed dramatically the watershed morphology. The condition of a sabodam can be very different even over a one month period (Feb. 2011 until Mar. 2011), see fig. 6(a) and (b). The hot pyroclastic material in Kali Gendol, fig. 6(d), could make the eggs overcooked, fig. 6(c).

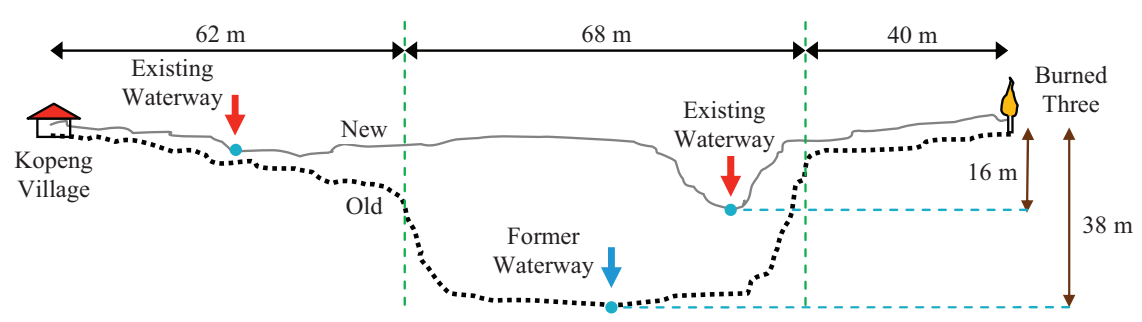

Figure 5: Rapid investigation measurement of a Kali Gendol cross section in Kopeng Village ( \pm 15 days after first eruption) showing the change in landscape caused by pyroclastic deposition.

(a)
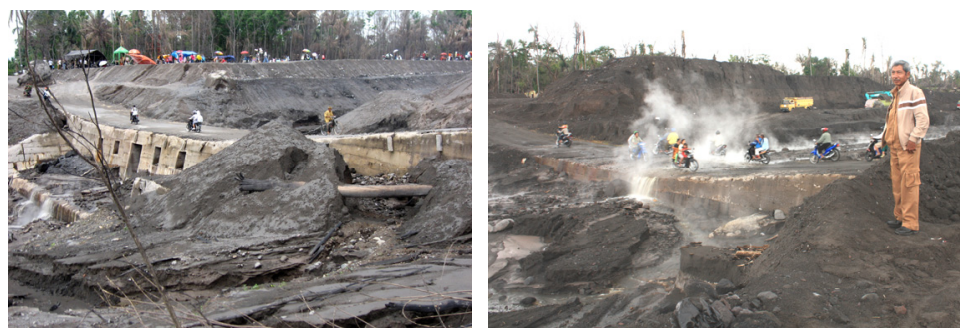

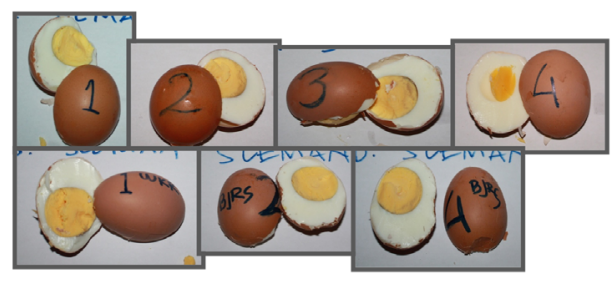

(c)

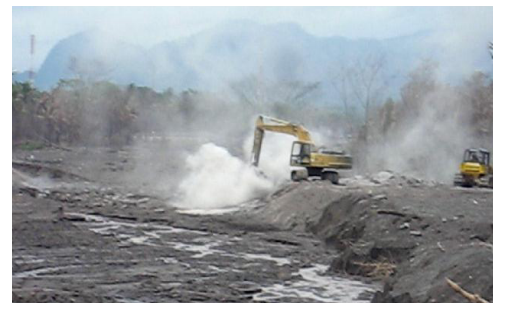

(d)

Figure 6: (a) One of Kali Gendol sabodams in February 2011. (b) The same dam in March 2011. (c) The egg that was boiled in hot pyroclastic material became overcooked. (d) The condition of pyroclastic deposits at Kali Gendol that were still very hot (14 January 2011). 


\subsection{Lahar river emergency rating}

The Kali Gendol watershed is the area most vulnerable to Lahar flow disaster, especially the area located from a height of about $500 \mathrm{~m}$ to $150 \mathrm{~m}$ above sea level. The vulnerability is clearly proven by the existence of a large quantity of pyroclastic deposits, which were lain down on the Mount Merapi hillside. The other facts of Kali Gendol Valley vulnerability are the changing landscape and the filling of the valley of Glendol River in 2010 post-eruption time so that the landscape is now changing into a relatively flat area.

Founded on previous circumstances, a minimum of $\sim 1.0 \times 10^{6} \mathrm{~m}^{3}$ (or $8 \%$ of total volume) of material was remobilized from the initial volume of pyroclastic deposits of $13.3 \times 10^{6} \mathrm{~m}^{3}$ in Kali Gendol, during the first rainy season, following the 2006 eruption of Mt. Merapi (Kelly et al. [15]). In fact, around the Mt. Merapi area, the considerable lahar flow did not occur simultaneously in several hazardous rivers, but occurred one after another. In accordance with pyroclastic deposit characteristics and watershed existing conditions, that fact can be used as an empirical basis for an emergency countermeasure priority rating of several lahar rivers, in the event of volcanic eruption.

\section{Conclusions}

After the 2010 Merapi eruption, pyroclastic deposits in Kali Gendol could resist the occurrence of lahar flow. The aspects that affect the resistance capacity are thickness, density, porosity, riverbed slope, rain intensity, and temperature of the pyroclastic deposits. Stakeholders should consider some points in preparing for short-term disaster mitigation accomplishments, as follows:

1. Protecting society and economic strategic areas along the watershed.

2. Securing general infrastructures, such as national roads and bridges.

3. Saving the historical and cultural heritage sites.

4. Maintaining the lahar rivers' function as a water reservation and drainage.

Although the Gendol Post Eruption situation is quite conducive regarding the lahar flow hazard, it does not excuse not giving priority to mitigation, reconstruction, and remediation of the natural environment of the Gendol watershed. The emergency countermeasure priority rating of several lahar rivers, in the event of volcanic eruption, can apply pyroclastic deposit characteristics and watershed existing conditions as an empirical background.

\section{Acknowledgements}

We express our profuse thanks to the Balai Sabo Surveying Team who, with great encouragement, performed tests on Hot and Dangerous Kali Gendol pyroclastic deposits, and also to all researchers who supported the completion of this research.

\section{References}

[1] Mudjiharto, et al, Cold Lava Flood of Mt. Merapi Eruption, Central Java Province, Republic of Indonesia, WHO Report, Situation Report SR (1) 02 
February 2011, Emergency and Humanitarian Action (EHA), WHO, Indonesia: Jakarta, pp. 1-5, 2011.

[2] Houghton, B., Rymer, H., Stix, J., Nutt, S. Mc., \& Sigurdsson, H., Encyclopedia of Volcanoes, Academic Press: USA, pp. 56-78, 1999.

[3] Kusumosubroto, H., 2006, Fenomena Aliran Debris dan Faktor Pembentuknya. Proc. of The Sabo Technology Dissemination Seminar, Ministry of Public Works, Indonesia: Semarang, pp. 12-24, 1984.

[4] Newhall, C.G.., et al, 10,000 Years of explosive eruptions of Merapi Volcano, Central Java: Archaeological and Modern Implications. Journal of Volcanology and Geothermal Research, 100, pp. 9-50, 2000.

[5] Bronto, S., \& Sayudi, S. D., Guidebook for Field Excursion on south and west slopes of Merapi Volcano: Volcanological Survey of Indonesia, Proc. of The Merapi Decade Volcano International Workshop, BPPTK: Yogyakarta, pp. 85-98, 1995.

[6] Andreastuti, S.D., Alloway, B.V., Smith, I.E.M., 2000. A detailed tephrostratigraphic framework at Merapi Volcano, Central Java, Indonesia: Implications for eruption prediction and hazard assessment. J. Volcanol. Geotherm. Res. 100, 51-67.

[7] Fossoul, F., Orban, P., \& Dassargues, A., Numerical Simulation of Heat Transfer Associated With Low Enthalpy Geothermal Pumping In an Alluvial Aquifer. Geologica Belgica, 14 (1-2), pp. 45-54, 2011.

[8] Fu, W. S., Wang, K.N., \& Ke, W.W., Heat Transfer of Porous Medium with Random Porosity Model In A Laminar Channel Flow. Journal of The Chinese Institute of Engineers, 24 (4), pp. 431-438, 2001.

[9] Legowo, D., Volcanic Debris Control Applied in Indonesia. The Journal of Hydrology, New Zealand, 20, pp. 122-134, 1981.

[10] Lavigne, F., et.al, Instrumental Lahar Monitoring at Merapi Volcano, Central Java, Indonesia. Journal of Volcanology and Geothermal Research, 100, pp. 457-478, 2000.

[11] Cully, A., Post-Eruption Lahar Triggers: slope failure and rainfall, Thesis at Department of Geography, University of British Columbia: Canada, pp. 95$115,2009$.

[12] Nandaka, IGM A., \& Asman, Model Simpel Elevasi Digital Puncak Merapi, Merapi. Periodic Bulletin, Balai Penyelidikan dan Pengembangan Teknologi Kegunungapian, 5, pp. 42-54, 2008.

[13] Pantakar, S., Numerical heat transfer and fluid flow, Taylor \& Francis: New-York, pp. 214, 1980.

[14] Shea, C. O., Volcanic Influence Over Fluvial Sedimentation in The Cretaceous Mc Dermott Member, Animas Formation, Southwestern Colorado, Thesis at Graduate College of Bowling Green State University, Bowling Green State University: USA, pp. 50-64, 2009.

[15] Kelly, M., Charbonnier, S., \& Gertisser, R., Volume and Extent of Lahar Reworking of the 2006 Pyroclastic Flow Deposits at Merapi Volcano, Java, Indonesia, Research Report, School of Physical and Geographical Sciences, Earth Sciences and Geography, Keele University: Keele, pp. 1, 2006. 